\title{
Symmetrical Peripheral Gangrene in Severe Plasmodium vivax Malaria
}

Sir,

Symmetrical peripheral gangrene (SPG) is defined as symmetrical distal ischemic change at two or more sites in the absence of any vasculitis or large-vessel obstruction. ${ }^{[1]}$ SPG caused by malaria is very rare, and most of the cases are associated with Plasmodium falciparum. Herein, we present a case of SPG due to severe Plasmodium vivax malaria.

A62-year-old female presented in the emergency department with complaints of fever for the last 4 days which was intermittent in nature and was associated with chills and rigor. On examination, she was febrile with an oral temperature of $104^{\circ} \mathrm{F}$. Her pulse rate was $120 / \mathrm{min}$, regular and all peripheral pulses were palpable, and blood pressure was $110 / 70 \mathrm{mmHg}$. There were multiple petechial spots over the lower limbs. Hemogram on the day of admission showed hemoglobin of $8.2 \mathrm{~g} / \mathrm{dl}$, total leukocyte count of 10,300/cumm (N73, L26, and E1), and platelet count of 22,000/cumm. Peripheral smear showed schizonts of $P$. vivax, and malaria kit test was also positive for $P$. vivax. Her renal (urea $-121 \mathrm{mg} / \mathrm{dl}$, creatinine $-2.3 \mathrm{mg} / \mathrm{dl}$ ) and liver function tests (bilirubin $-2.7 \mathrm{mg} / \mathrm{dl}$, aspartate aminotransferase - $520 \mathrm{IU} / \mathrm{L}$, alanine aminotransferase - $455 \mathrm{IU} / \mathrm{L}$, and alkaline phosphatase - $258 \mathrm{U} / \mathrm{L}$ ) were also deranged. Blood sugar was $40 \mathrm{mg} / \mathrm{dl}$, and all electrolytes were normal except corrected serum calcium which was $7.5 \mathrm{mg} / \mathrm{dl}$ (normal: $8.5-10.5 \mathrm{mg} / \mathrm{dl}$ ). Arterial blood gas analysis showed metabolic acidosis $\left(\mathrm{pH}-7.29, \mathrm{pCO}_{2}-30.2 \mathrm{mmHg}\right.$, $\mathrm{pO}_{2}-62.5 \mathrm{mmHg}$, and bicarbonate $-14.5 \mathrm{mEq} / \mathrm{L}$ ). Serum lactate dehydrogenase was $6690 \mathrm{U} / \mathrm{L}$ (normal: 200-400 U/L) and urinalysis was normal. A diagnosis of severe $P$. vivax malaria was made and she was started on injection artesunate at dose of $2.4 \mathrm{mg} / \mathrm{kg}$. Dextrose containing intravenous fluid and oral paracetamol was given for hypoglycemia and

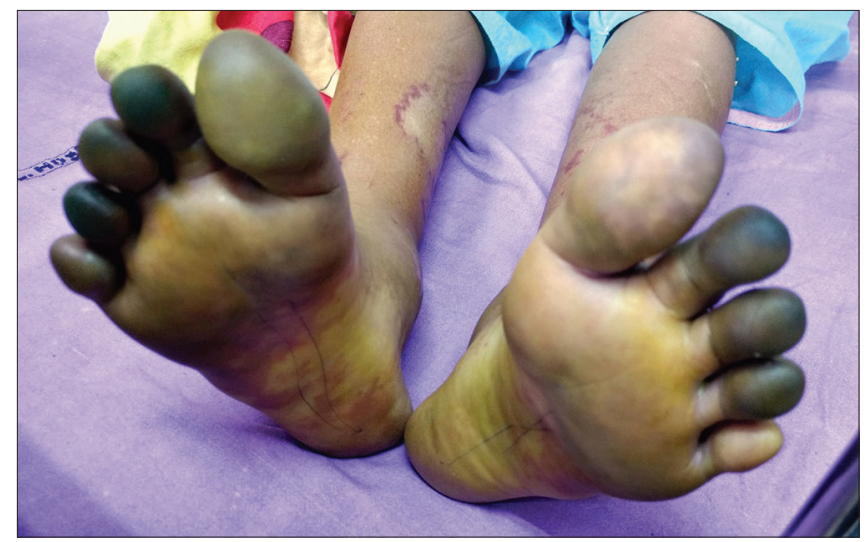

Figure 1: Blackish discoloration of lower limb digits with petechial rash over shin fever, respectively. On the $3^{\text {rd }}$ day of admission, she started complaining of burning sensation in her feet and right hand with blackish discoloration [Figures 1 and 2]. All peripheral pulses including dorsalis pedis were palpable. Prothrombin time was $10 \mathrm{~s}$ (normal: $11-15 \mathrm{~s}$ ), activated partial thromboplastin time was $35 \mathrm{~s}$ (normal: $22-34 \mathrm{~s}$ ), and D-dimer was $12 \mathrm{mcg} / \mathrm{ml}$ (normal: $<0.50 \mathrm{mcg} / \mathrm{ml}$ fibrinogen equivalent units). Fibrin degradation product was $32 \mathrm{mcg} / \mathrm{ml}$ (normal: $<10 \mathrm{mcg} / \mathrm{ml}$ ). Other investigations such as blood culture, urine culture, HIV, hepatitis B surface antigen, anti-hepatitis C virus, anti-nuclear antibody, and antiphospholipid antibody were normal. Ultrasound abdomen, arterial Doppler of limbs, and echocardiography were normal. Injection artesunate was continued for 5 days and her platelet count improved to 1.6 lacs/cumm; she was then given 3 days course of artemisinin-based combination therapy (artemether and lumefantrine). However, there was gradual worsening of renal and liver function tests for which she received two cycles of hemodialysis. Blackish discoloration of hand and feet gradually progressed to develop dry gangrene by the end of $2^{\text {nd }}$ week [Figure 3]. At time of discharge from the hospital, she was afebrile and all biochemical parameters were normal. She was discharged on tablet primaquine at a dose of $0.25 \mathrm{mg} / \mathrm{kg} /$ day for 2 weeks after testing glucose-6-phosphate dehydrogenase levels. She was further advised to follow-up in the Surgery Department for amputation of digits.

The mechanism of SPG in falciparum malaria is not known and is believed that heavy parasitemia causes activation of complement and coagulation pathway which eventually leads to thrombosis of microvasculature. ${ }^{[2]}$ Infected erythrocytes interact with various endothelial receptors such as intercellular cell adhesion molecule-1, vascular cell

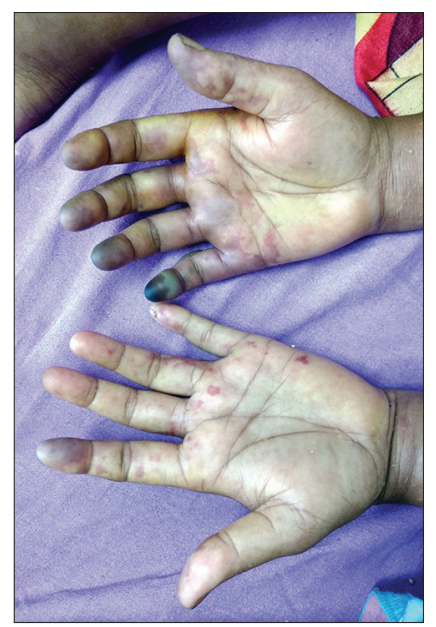

Figure 2: Blackish discoloration of fingers of the right hand 


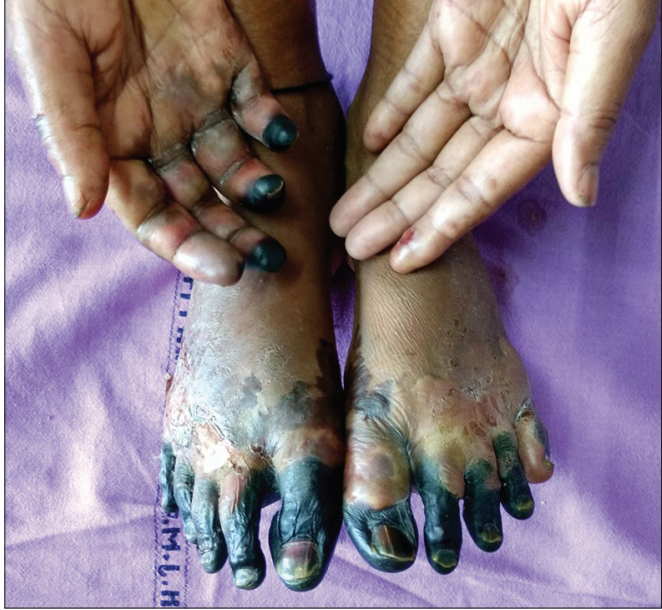

Figure 3: Mummification of toes and fingers of the right hand after 2 weeks

adhesion molecule-1, thrombospondin, and histidine-rich protein causing microcirculatory obstruction..$^{[3]}$ Disseminated intravascular coagulation is also a contributing factor in malaria-related SPG and is rarely associated with significant bleeding. ${ }^{[4]}$ Management of SPG in malaria is supportive. There is no specific treatment for SPG per se and routine use of antiplatelets or anticoagulants is not indicated. The mortality rate of SPG is almost $35 \%$ and $70 \%-90 \%$ patients might need amputation after line of demarcation develops. ${ }^{[5]}$

\section{Financial support and sponsorship}

Nil.

\section{Conflicts of interest}

There are no conflicts of interest.

Prabhat Kumar, Ghazal Tansir, Harish Gupta, Juhi Dixit Department of Medicine, PGIMER and Dr RML Hospital, New Delhi, India
Address for correspondence: Dr. Prabhat Kumar First Floor 33/22 (Backside), West Patel Nagar, New Delhi - 110 008, India. E-mail:drkumar.prabhat@gmail.com

\section{References}

1. McGouran RC, Emmerson GA. Symmetrical peripheral gangrene. $\mathrm{Br}$ Heart J 1977;39:569-72.

2. Phillips RE, Looareesuwan S, Warrell DA, Lee SH, Karbwang J, Warrell MJ, et al. The importance of anaemia in cerebral and uncomplicated falciparum malaria: Role of complications, dyserythropoiesis and iron sequestration. Q J Med 1986;58:305-23.

3. Rojanasthien $\mathrm{S}$, Surakamolleart V, Boonpucknavig S, Isarangkura P. Hematological and coagulation studies in malaria. J Med Assoc Thai 1992;75 Suppl 1:190-4.

4. Molos MA, Hall JC. Symmetrical peripheral gangrene and disseminated intravascular coagulation. Arch Dermatol 1985;121:1057-61.

5. Ghosh SK, Bandyopadhyay D, Ghosh A. Symmetrical peripheral gangrene: A prospective study of 14 consecutive cases in a tertiary-care hospital in Eastern India. J Eur Acad Dermatol Venereol 2010;24:214-8

This is an open access article distributed under the terms of the Creative Commons Attribution-NonCommercial-ShareAlike 3.0 License, which allows others to remix, tweak, and build upon the work non-commercially, as long as the author is credited and the new creations are licensed under the identical terms.

\begin{tabular}{|l|l|}
\hline \multicolumn{3}{|c|}{ Access this article online } \\
\hline Quick Response Code: & Website: \\
\hline & www.ijccm.org \\
\hline
\end{tabular}

How to cite this article: Kumar P, Tansir G, Gupta H, Dixit J. Symmetrical peripheral gangrene in severe Plasmodium vivax malaria. Indian J Crit Care Med 2017;21:245-6.

(c) 2017 Indian Journal of Critical Care Medicine | Published by Wolters Kluwer - Medknow 